Doi: HTTPS://DOI.ORG/10.23910/2/2020.0369

\title{
Analysis of Agriculture Input Consumption by Indian Farmers
}

\author{
Ankit Pathania*, Rashmi Chaudhary, Krishan Kumar
}

Dr. Yashwant Singh Parmar University of Horticulture \& Forestry, Nauni, Solan, H.P. (173 230), India

\section{Corresponding Author}

Ankit Pathania

e-mail: ankitpathania6067@gmail.com

\author{
Article History \\ Article ID: IJEP0369 \\ Received in $22^{\text {nd }}$ March, 2020 \\ Received in revised form $06^{\text {th }}$ April, 2020 \\ Accepted in final form $14^{\text {th }}$ April, 2020
}

\begin{abstract}
Agriculture has always been a lifeline of the Indian economy as it provides livelihood and employment to more than $54 \%$ of the population. It also contributes around $13.9 \%$ to the gross domestic product of the country. The backbone of any agricultural revolution is the access of farmers to modern agricultural inputs. These agricultural inputs range from improved seeds, fertilizers and crop protection chemicals to machinery, irrigation and knowledge etc. Keeping this in the background, the present study was carried out to make an analysis of agricultural inputs usages by the Indian farmers. The data for the present study were mainly sourced from various government published reports like agriculture statistical at a glance, 2018 and agricultural research data book, 2018. The analysis of the information was performed using annual growth rate, percentage and compound annual growth rate from 2001-02 to 2017-18. The study resulted in that input-consumption in the agriculture sector has expanded to a large extent during the study period and showing an increasing trend in the consumption-status of most of the agricultural inputs like certified/quality seeds, fertilizers, pesticides, farm machinery and electricity. Furthermore, it can be suggested that agricultural inputs have a huge potential to scale-up and maximizing agricultural productivity in the country.
\end{abstract}

Keywords: Agriculture, agricultural input, consumption, farmers

\section{Introduction}

Agriculture has always been a lifeline of the Indian economy as it provides livelihood and employment to more than $54 \%$ of the population and contributes around $13.9 \%$ to the gross domestic product of the country. The agriculture and allied sector continue to be pivotal to the sustainable growth and development of the Indian economy. Not only does it meet the food and nutritional requirements of 1.3 billion Indians, but it also contributes significantly to production, employment and demand generation through various backward and forward linkages. Moreover, the role of the agricultural sector in alleviating poverty and in ensuring the sustainable development of the economy is well established (Ganesan and Pushpavalli, 2017). The backbone of any agricultural revolution is the access of farmers to modern agricultural inputs. These agricultural inputs range from improved seeds, fertilizers and crop protection chemicals to machinery, irrigation and knowledge etc (Sahel, 2014). Agricultural inputs are classified into different categories. Dogra and Ghuman (2007), Dharni and Singh (2011) classified the agricultural inputs broadly into consumable and durables. The consumable inputs comprise seeds, fertilizers, pesticides, etc. which are required for the farming season after season. Whereas the durable capital inputs comprise tractors, harvesters, threshers, pump sets, and like which are purchased by the farmers once in the lifetime. Classification based on the frequency of purchase puts agricultural inputs into routinely purchased and infrequently purchased categories (Kool et al., 1997; Kumar and Kapoor, 2015). Assael (1998) studied the decision-making process by adding one more factor, namely level of involvement to classify inputs. Agricultural inputs are important for small farmers in terms of yield enhancement, cost-cutting, and better quality production for better price realization. The availability, accessibility, quality and price have been a major issue in this sector from the farmer perspective. There are issues of lack of availability of major consumable inputs especially in seed and crop protection products in adequate quantity on time and reliable quality. Therefore, the present study was carried out to analyze agricultural inputs consumption of the Indian farmers during 2001-02 to 2017-18.

\section{Materials and Methods}

The data for the present study were sourced from various government published reports. The data on the crop-wise distribution of seeds, fertilizers consumption, and pesticides consumption were collected from the Agriculture Statistical 
at a Glance- 2018 and ICAR- Agricultural Research Data Book, 2018. Besides, data on the use of agricultural engineering inputs in India was collected from tractors association of India. The paper covers the information related to agricultural inputs from 2001-02 to 2017-2018. As far as the statistical tool for analysis is concerned, the annual growth rate and percentage were used to find out the growth performance of selected agriculture inputs over the years. The compound annual growth rate was also estimated from 2001-02 to 201718 to determine the overall performance of agriculture input sector in India.

\section{Results and Discussion}

\subsection{Certified/quality seeds}

A seed is a basic input and the most important catalyst for other inputs to be cost-effective. Therefore, it assumes primary importance in agricultural inputs. It is evident from Table 1 that during the study period there has been an increasing trend in the usage of certified/quality seeds. In 2001-02, total seeds consumption was 91.80 lakh quintals and which increased to 352.01 lakh quintals in 2017-18 with CAGR of $8.23 \%$. However, it can be concluded that throughout the

Table 1: Crop-wise distribution of certified/quality seeds (lakh qtls) in India and its growth rate during 2001-02 to 2017-18

\begin{tabular}{lcccccccc}
\hline Year & $\begin{array}{c}\text { Cereals } \\
\text { (lakh qtls) }\end{array}$ & $\begin{array}{c}\text { Pulses } \\
\text { (lakh qtls) }\end{array}$ & $\begin{array}{c}\text { Oilseeds } \\
\text { (lakh qtls) }\end{array}$ & $\begin{array}{c}\text { Fibres } \\
\text { (lakh qtls) }\end{array}$ & $\begin{array}{c}\text { Potato } \\
\text { (lakh qtls) }\end{array}$ & $\begin{array}{c}\text { Others } \\
\text { (lakh qtls) }\end{array}$ & $\begin{array}{c}\text { Total } \\
\text { (lakh qtls) }\end{array}$ & $\begin{array}{c}\text { Growth } \\
\text { rate (\%) }\end{array}$ \\
\hline $2001-02$ & 65.56 & 4.69 & 12.10 & 2.89 & 6.33 & 0.23 & 91.80 & - \\
$2002-03$ & 66.97 & 6.60 & 13.36 & 2.74 & 7.16 & 0.21 & 97.04 & 5.71 \\
$2003-04$ & 77.82 & 8017 & 19.39 & 2.78 & 7.01 & 0.23 & 108.40 & 11.71 \\
$2004-05$ & 81.41 & 7.40 & 23.42 & 2.76 & 5.05 & 0.22 & 120.26 & 10.94 \\
$2005-06$ & 86.73 & 7.37 & 24.35 & 2.89 & 5.08 & 0.33 & 126.75 & 5.40 \\
$2006-07$ & 109.87 & 9.63 & 27.00 & 3.05 & 5.12 & 0.34 & 155.01 & 22.30 \\
$2007-08$ & 123.80 & 12.57 & 34.33 & 2.63 & 5.35 & 0.37 & 179.05 & 15.51 \\
$2008-09$ & 147.43 & 14.48 & 39.92 & 2.58 & 10.55 & 0.85 & 215.81 & 20.53 \\
$2009-10$ & 165.15 & 19.69 & 50.71 & 2.65 & 18.68 & 0.23 & 257.11 & 19.14 \\
$2010-11$ & 182.62 & 20.83 & 50.61 & 2.64 & 20.08 & 0.55 & 277.34 & 7.87 \\
$2011-12$ & 189.96 & 22.26 & 61.49 & 3.09 & 16.68 & 1.64 & 294.85 & 6.31 \\
$2012-13$ & 204.37 & 24.51 & 58.41 & 2.95 & 21.47 & 1.73 & 313.44 & 6.30 \\
$2013-14$ & 183.03 & 27.80 & 61.09 & 2.87 & 24.63 & 1.97 & 301.39 & -3.84 \\
$2014-15$ & 203.20 & 24.77 & 43.03 & 3.86 & 28.12 & 0.14 & 303.12 & 0.57 \\
$2015-16$ & 194.95 & 22.71 & 47.44 & 2.49 & 33.88 & 2.57 & 304.04 & 0.30 \\
$2016-17$ & NA & NA & NA & NA & NA & NA & 348.58 & 14.65 \\
$2017-18$ & NA & NA & NA & NA & NA & NA & 352.01 & 0.98 \\
CAGR (\%) & 7.54 & 11.09 & 9.54 & -0.99 & 11.83 & 17.50 & 8.23 & \\
\hline
\end{tabular}

Source: ICAR Agricultural Research Data Book, 2018

study period, the total consumption of all types of certified/ quality seeds has shown the positive growth rate over the respective years except during 2013-14.

\subsection{Fertilizers}

Fertilizer is another important agricultural input consists of three major elements nitrogen, phosphorus, and potash known as NPK and with the development of scientific agriculture and introduction of modern technology the importance of chemical fertilizer has increased. It can be depicted from Table 2 that the study shows moderate growth in fertilizers consumption during the study period. In 2001-02, total fertilizer consumption was 17359.7 thousand tonnes (in terms of NPK nutrients) and it raised to 26590.9 thousand tonnes in 2017-2018. The compound annual growth for fertilizers consumption was worked out $2.54 \%$ during the study period. Further, it can be observed that there has been negative growth in the consumption of total fertilizers in six years during the study period i.e., 2002-03, 2010-11, 2011-12, 2012-13 and 2013-14 and 2016-17.

\subsection{Pesticides}

Pesticides are the other major chemical input used in agriculture which reduces the losses in terms of both quantity and quality of farm produce from various weeds, insects, pests and diseases. From Table 3 it can be observed that the total pesticides consumption recorded in the year 2001-02 was about 47.03 tonnes and it dropped to 41.82 tonnes in 2009-10 and then increased to 55.54 tonnes in 2010-11. It shows the highest consumption in the year 2013-14 i.e. 60.28 tonnes 


\begin{tabular}{|c|c|c|c|c|c|}
\hline Year & $\begin{array}{c}\mathrm{N} \\
\text { (Thou- } \\
\text { sand } \\
\text { tonnes) }\end{array}$ & $\begin{array}{c}\mathrm{P} \\
\text { (Thou- } \\
\text { sand } \\
\text { tonnes) }\end{array}$ & $\begin{array}{c}\mathrm{K} \\
\text { (Thou- } \\
\text { sand } \\
\text { tonnes) }\end{array}$ & $\begin{array}{l}\text { Total } \\
\text { (Thou- } \\
\text { sand } \\
\text { tonnes) }\end{array}$ & $\begin{array}{c}\text { Growth } \\
\text { Rate } \\
(\%)\end{array}$ \\
\hline 2001-02 & 11310.2 & 4382.4 & 1667.1 & 17359.7 & - \\
\hline 2002-03 & 10474.1 & 4018.8 & 1601.2 & 16094.1 & -7.29 \\
\hline 2003-04 & 11077.0 & 4124.3 & 1597.9 & 16799.2 & 4.38 \\
\hline 2004-05 & 11713.9 & 4623.8 & 2060.6 & 18398.3 & 9.52 \\
\hline 2005-06 & 12723.3 & 5203.7 & 2413.5 & 20340.5 & 10.56 \\
\hline 2006-07 & 13772.9 & 5543.3 & 2334.8 & 21651.0 & 6.44 \\
\hline 2007-08 & 14419.1 & 5514.7 & 2636.3 & 22570.1 & 4.25 \\
\hline 2008-09 & 15090.5 & 6506.2 & 3312.6 & 24909.3 & 10.36 \\
\hline 2009-10 & 15580.0 & 7274.0 & 3632.4 & 26486.4 & 6.33 \\
\hline 2010-11 & 16558.2 & 8049.7 & 3514.3 & 28122.2 & 6.18 \\
\hline 2011-12 & 17300.3 & 7914.3 & 2575.5 & 27790.0 & -1.18 \\
\hline $2012-13$ & 16820.9 & 6653.4 & 2061.8 & 25536.2 & -8.11 \\
\hline 2013-14 & 16750.1 & 5633.5 & 2098.9 & 24482.4 & -4.13 \\
\hline 2014-15 & 16945.4 & 6098.4 & 2532.3 & 25576.1 & 4.47 \\
\hline $2015-16$ & 17372.3 & 6978.8 & 2401.5 & 26752.6 & 4.60 \\
\hline 2016-17 & 16735.4 & 6705.4 & 2508.3 & 25949.2 & -3.00 \\
\hline 2017-18 & 16958.0 & 6854.1 & 2778.8 & 26590.9 & 2.47 \\
\hline CAGR (\%) & 2.41 & 2.67 & 3.05 & 2.54 & \\
\hline
\end{tabular}

Source: ICAR Agricultural Research Data Book, 2018

with a growth rate of $32.14 \%$. The CAGR for the pesticides consumption was worked out 1.26\% from 2001-02 to 2017-18.

\subsection{Electricity}

Modern agriculture requires an energy input at all stages of agricultural production such as direct use of energy in farm machinery, water management, irrigation, cultivation and
Table 3: Consumption-status of pesticides (Technical Grade) in India and its annual growth rate during 2001-02 to $2017-18$

\begin{tabular}{lcc}
\hline Year & $\begin{array}{c}\text { Total consumption of pesticides } \\
\text { (Technical grade material) in tonnes }\end{array}$ & $\begin{array}{c}\text { Growth } \\
\text { rate (\%) }\end{array}$ \\
\hline $2001-02$ & 47.02 & - \\
$2002-03$ & 48.35 & 2.83 \\
$2003-04$ & 41.02 & -15.16 \\
$2004-05$ & 40.67 & -0.85 \\
$2005-06$ & 39.77 & -2.21 \\
$2006-07$ & 43.41 & 9.15 \\
$2007-08$ & 41.64 & -4.08 \\
$2008-09$ & 43.86 & 5.33 \\
$2009-10$ & 41.82 & -4.65 \\
$2010-11$ & 55.54 & 32.81 \\
$2011-12$ & 52.98 & -4.61 \\
$2012-13$ & 45.62 & -13.89 \\
$2013-14$ & 60.28 & 32.14 \\
$2014-15$ & 56.12 & -6.90 \\
$2015-16$ & 54.12 & -3.56 \\
$2016-17$ & 52.75 & -2.53 \\
$2017-18$ & 58.16 & 10.26 \\
CAGR (\%) & 1.26 & \\
\hline SOUrCe: & &
\end{tabular}

Source: ICAR Agricultural Research Data Book, 2018

harvesting. Post-harvest energy use includes energy for food processing, storage and transport to markets. The information on the consumption status of electricity in agricultural sector presented in table 4 indicates that the growth rate of electricity for agricultural purposes was highest during 200102. The data shows that the share of agricultural consumption to total consumption is decreasing over the study period which is reported $20.91 \%$ in $2017-18$ as $25.33 \%$ in $2001-02$.

Table 4: Consumption-status of electricity for agricultural purposes and its share in total electricity consumption in India during 2001-02 to 2016-17

\begin{tabular}{lcccc}
\hline Year & $\begin{array}{c}\text { Consumption for } \\
\text { agricultural purposes } \\
(\text { GWh })\end{array}$ & $\begin{array}{c}\text { Total consumption } \\
(\mathrm{GWh})\end{array}$ & $\begin{array}{c}\text { Share of agricultural } \\
\text { consumption to total } \\
\text { consumption (\%) }\end{array}$ & $\begin{array}{c}\text { Rate of change in percentage of } \\
\text { agricultural consumption to } \\
\text { total consumption }\end{array}$ \\
\hline $2001-02$ & 81673 & 322459 & 25.33 & - \\
$2002-03$ & 84486 & 339598 & 24.88 & -1.78 \\
$2003-04$ & 87089 & 360937 & 24.13 & -3.01 \\
$2004-05$ & 88555 & 386134 & 22.93 & -4.97 \\
$2005-06$ & 90292 & 411887 & 21.92 & -4.40 \\
$2006-07$ & 99023 & 455748 & 21.73 & -0.87 \\
$2007-08$ & 104182 & 501977 & 20.75 & -4.51 \\
\hline
\end{tabular}

Table 4: Continue... 


\begin{tabular}{|c|c|c|c|c|}
\hline Year & $\begin{array}{c}\text { Consumption for } \\
\text { agricultural purposes } \\
\text { (GWh) }\end{array}$ & $\begin{array}{c}\text { Total consumption } \\
\text { (GWh) }\end{array}$ & $\begin{array}{l}\text { Share of agricultural } \\
\text { consumption to total } \\
\text { consumption (\%) }\end{array}$ & $\begin{array}{c}\text { Rate of change in percentage of } \\
\text { agricultural consumption to } \\
\text { total consumption }\end{array}$ \\
\hline 2008-09 & 107776 & 527564 & 20.43 & -1.54 \\
\hline $2009-10$ & 119492 & 569718 & 20.98 & -2.69 \\
\hline 2010-11 & 126377 & 616969 & 20.48 & -2.38 \\
\hline 2011-12 & 140960 & 672933 & 20.95 & 2.29 \\
\hline $2012-13$ & 147462 & 708843 & 20.80 & -0.72 \\
\hline 2013-14 & 152744 & 751908 & 20.31 & -2.36 \\
\hline 2014-15 & 168913 & 814250 & 20.74 & 2.12 \\
\hline $2015-16$ & 173185 & 863364 & 20.06 & -3.28 \\
\hline 2016-17 & 191151 & 914093 & 20.91 & 4.24 \\
\hline CAGR (\%) & 5.46 & 6.73 & & \\
\hline
\end{tabular}

Source: Agricultural statistics at a glance, 2018

\subsection{Agricultural engineering inputs}

The sale of tractors and power tillers was considered to depict the growth in agricultural machinery. The sales data presented in table 5 shows that this industry had experienced robust growth during the latter half of the 2000s. In 2000-01,

Table 5: Sale-status of agricultural engineering inputs in India and its annual growth rate during 2001-02 to 2017-18

\begin{tabular}{|c|c|c|c|c|}
\hline Year & $\begin{array}{l}\text { No. of Trac- } \\
\text { tors sold and } \\
\text { exported }\end{array}$ & $\begin{array}{c}\text { Growth } \\
\text { rate } \\
(\%)\end{array}$ & $\begin{array}{c}\text { Number of } \\
\text { Power til- } \\
\text { ler sold }\end{array}$ & $\begin{array}{c}\text { Growth } \\
\text { rate } \\
(\%)\end{array}$ \\
\hline 2001-02 & 217456 & - & 13563 & - \\
\hline 2002-03 & 168182 & -22.66 & 14613 & 7.74 \\
\hline 2003-04 & 189518 & 12.69 & 15665 & 7.20 \\
\hline 2004-05 & 246469 & 30.05 & 17481 & 11.60 \\
\hline 2005-06 & 291680 & 18.34 & 23030 & 31.74 \\
\hline 2006-07 & 352827 & 20.96 & 24791 & 7.64 \\
\hline 2007-08 & 346501 & -1.79 & 26135 & 5.42 \\
\hline 2008-09 & 347010 & 0.15 & 35331 & 35.18 \\
\hline $2009-10$ & 440331 & 26.89 & 43464 & 23.01 \\
\hline 2010-11 & 545109 & 23.80 & 51414 & 18.30 \\
\hline 2011-12 & 607658 & 11.47 & 57232 & 11.31 \\
\hline $2012-13$ & 590672 & -2.80 & 51237 & -10.47 \\
\hline 2013-14 & 696828 & 17.97 & 53927 & 5.25 \\
\hline 2014-15 & 626839 & -10.04 & NA & - \\
\hline 2015-16 & 571249 & -8.87 & NA & - \\
\hline 2016-17 & 777914 & 36.18 & NA & - \\
\hline 2017-18 & 796873 & 2.44 & NA & - \\
\hline CAGR (\%) & 7.94 & & 11.2 & \\
\hline
\end{tabular}

Source: ICAR Agricultural Research Data Book, 2018 the machinery sales were about 270 thousand and it raised to 347 thousand in 2008-09, and since then it has nearly doubled reaching about 700 thousand by the end of 201314 . Whereas in case of power tillers, it was 13 thousand in 2001-02 and raised to four times i.e. 54 thousand in the year 2017-18. The compound annual growth rate for tractors and power tiller were worked out 7.94 and $11.2 \%$ respectively for the study period.

\section{Conclusion}

It has been noticed from the study that input-use has expanded to a large extent during the study period and showing an increasing trend in the consumption of most of the agricultural inputs like certified/quality seeds, fertilizers, pesticides, farm machinery and electricity consumption. Furthermore, it can be suggested from the study that agricultural inputs have a huge potential to scale-up and maximizing agricultural productivity in the country.

\section{References}

Assael, H., 1998. Consumer behaviour and marketing action. (6 $6^{\text {th }}$ Edn.). South-Western College Publishing OH, 42.

Dharni, K., Singh, K., 2011. Buying behaviour of agri-input customers of organised rural retail outlet. The IUP Journal of Management Research 10, 14-30.

Dogra, B., Ghuman, K., 2007. Marketing of agricultural inputs: Rural marketing concepts and practices. Tata McGraw Hill, New Delhi, 9-10.

Ganesan, L., Pushpavalli, K., 2017. Utilization of agriculture inputs and its outcome in Indian agriculture. Shanlax International Journal of Economics 5, 65-79.

Government of India., 2018. Agricultural Research Data Book, Department of Agriculture and Cooperation, Ministry of Agriculture, New Delhi.

Government of India., 2018. Agricultural Statistics at a Glance, Directorate of Economics and Statistics, Department of 
Agriculture and Cooperation, Ministry of Agriculture, New Delhi.

Kool, M., Meulenberg, M., Broens, D.F., 1997. Extensiveness of farmers' buying processes. Agribusiness 13, 301-318. Kumar, N., Kapoor, S., 2017. Extensiveness of farmers' buying process of agri-inputs in India: implications for marketing. Journal of Agribusiness in Developing and Emerging Economies 7, 35-51.

Sahel, 2014. https://sahelcp.com./why-are-agriculturalinputs-important/Accessed in October 2014. 